\title{
ETHICAL LEADERSHIP: A VERITABLE TOOL FOR NATIONAL TRANSFORMATION, PEACE AND SOCIAL JUSTICE
}

\author{
Gabriel Asuquo ${ }^{1}$, Akerele Peter Adelaja ${ }^{2}$ \\ 1, College of Social and Management Sciences, Achievers University, Owo, Nigeria. \\ ${ }^{2}$ Department of Crimology and Security Studies, College of Social and Management Sciences \\ Achievers University, Owo, Ondo State, Nigeria \\ gabrielmarcel76@yahoo.com ${ }^{1}$
}

\begin{abstract}
For sundry reasons, every human community is replete with aberrations of varying magnitude. Some aberrations become so through the criminalisation process by society, some other human acts are considered ontologically uncongenial to human nature. Driving on the left lane of the road in Nigeria, for example, is a traffic offence. It is so because Nigerian road traffic experts consider it convenient to keep right while driving, thereby criminalising driving on the left lane of the road. The aberration of driving on the left lane of the road cannot be said to be adorned with ontological colouration. The phenomenon of rape is considered an ontological aberration in this article and repugnant to human nature. Both the victim and the perpetrator of rape are exposed to social and psychological repercussions. Unfortunately, some of the repercussions on the victim of rape are unnecessary, as they are cosmetically imposed by society, and there is no necessary connection between the aberration and the social consequences. Some of the social and psychological consequences of the phenomenon of rape are considered in this work, and it is argued herein that the social consequences imposed on the victim of rape are unnecessary, and that they unnecessarily compound the traumas that the rape-victim suffers. It is, therefore, suggested herein that some cultural perceptions among most Nigerian tribes should be reviewed to ameliorate the repercussions of rape in the rape-victim.
\end{abstract}

Keywords: Ethical Leadership, Nigeria, Social Justice, National Transformation.

\section{INTRODUCTION}

This paper set out to outline and prescribe the imperatives of ethical leadership for political governance, which will fast-track National transformation, in order, address the problems of peace-building and social injustice in Nigeria. The paper argues the thesis that until our ruling class imbibes the imperatives of ethical leadership, the Nigerian dream of national transformation, will remain an illusion or wishful thinking. This is because leadership shaped culture and values, in turn, culture and values shaped society. Thus, the merit of this paper is based on the need to address the questions of nation-building in Nigeria, which is a recurrent theme in political discourse in recent times. One of the questions of nation-building in Nigeria is how Nigeria can manage and harmonize her diversities in a more concerted manner that will inspire the spirit of nationalism across the country. Hence, the act of inspiring patriotism and nationalism among Nigerians rests squarely on Leadership that understands ethical imperatives.

According to Maxwell (2016:19), "leadership starts with influence and builds from there, that is, everything rises and falls on leadership". By implication, if we want to influence changes that are systemic in any organization, institution or country, it must start from its leadership ethos and mindset. In other words, the people who manage and administer the country must have a strong leadership philosophy that will affect the way they do things in the country. Hence, Nigerian as a country cannot rise beyond her leadership ethos, because, the way a country develops and make progress is tied to her leadership ethos. Singapore has proved this during the regime of Lee Kuan Yew, whereby the country moves from a third world country to an industrial hub in the world (Wikipedia, 
2019). The country has achieved remarkable feats in education, technology, and industrialization which has promoted the national transformation that they are witnessing today (Lee Kuan Yew, 2000). In Africa, Rwanda under Paul Kagame is setting the pace for African leadership through prudent management of resources and leadership by example. This is a country that was torn apart by genocide which was instigated by ethnic rivalry, and today she has rewritten her story and is making progress that is attracting global attention (Moghalu, 2018). What do all these hold for Nigeria?

According to Achebe (1989:1), "the trouble with Nigeria is simply and squarely a failure of leadership. There is nothing basically wrong with the Nigerian character. There is nothing wrong with the Nigerian land or climate or water or air or anything else". Similarly, Ochulor (2011) opines that leadership failure in Nigeria is caused by misrule on the part of leaders and the led. Hence, to address the problem of leadership failure Ochulor (2011), submits that Nigerians need an attitudinal change, in order to enthrone good leadership. Although, we agree with Achebe's and Ochulor's positions that, the trouble with Nigeria is squarely a leadership failure and the manifestation of this failure is misrule on the part of leaders and the led, but the paper is of the view that, leadership failure in Nigeria is because our leaders lack a strong leadership ethos. Therefore, to address this problem we need a new leadership philosophy that is based on the ideals of the Nigerian State which will be grounded on African ethics. The problem is not just attitudinal change but what can replace the current attitude, which is stopping the wheel of national transformation in Nigeria.

However, many commentators and social analysts have submitted that the problem with Nigeria is tribalism, religion, and political leaning. These on the surface look true but on a deeper reflection, we will see that they are symptoms of a national malady. The issue is the failure of leadership to craft-out universal valid principles of social justice and fairness in the ownership and sharing of resources and opportunities in Nigeria. Since Leadership has failed to do this, our elites in the process of politicking, employ tribalism, religion and political leaning as tools for scrambling for resources and opportunities. This is the Nigerian Problem and every other thing just adds up to make it look complicated. Hence, Nigeria needs Ethical leaders who will redefine national values and culture that will shape the Nigerian society, so as, to enthrone national transformation which will address the problem of social injustice, violent conflicts and ethnoreligious intolerance that is prevalent in Nigeria.

Thus, in this paper we shall look at the meaning of ethical leadership, its foundation and imperatives, also we shall look at national transformation and how ethical leadership can make it happen in Nigeria.

\section{CONCEPTUAL CLARIFICATION}

We shall consider two concepts that fall within the context of our discourse. They include ethical leadership and national transformation.

\section{Ethical Leadership}

Ethical leadership is a construct of two words ethics and leadership. Ethics is a philosophical term originating from the Greek word "ethos" meaning custom or character. It is concerned with prescribing moral requirements for good behaviour, which suggests that there are acceptable and unacceptable ways of behaving, which falls within the ambit of philosophical reflections (Minkes, Small, \& Chatterjee, 1999). Therefore, the ultimate concern of ethics as a branch of philosophy is, how to live a good life based on a rational principle of morality. Thus, to be ethical is to behave in morally acceptable ways that are 
in line with a society's values. On the other hand, Leadership is the ability to influence people to achieve set objectives. Succinctly put, Iroegbu (2005:247) defines leadership as "the responsibility of conducting $a$ people or group towards the achievement of determined goals. It entails being in charge, as well as having the power to direct the affairs of such people to arrive at expected results". Although, Iroegbu gave a general definition of leadership our concern is on political leadership, that is, the leadership of a country or political entity.

Within the context of this paper, ethical leadership is the critical appropriation and embodiment of traditions that have shaped the character and shared meanings of a person. Ethical leaders, therefore, are leaders whose characters have been shaped by the wisdom, habits, and practices of particular traditions, often more than one, yet they tend to be identified with a particular cultural ethos and narratives. Finally, ethical leadership asks the question of values about the ultimate concern. This definition of ethical leadership forms the core of our discourse. This is because an ethical leader is a person, who is living up to the principles of conduct that forms the character and values of a people; and is crucial for him and the society in which he/she is leading. However, to give the concept a practical application, Mihelič, Lipičnik, and Tekavčič (2010:1) opine that: "Ethical leaders think about long-term consequences, drawbacks, and benefits of the decisions they make in the organization or country. They are humble, concerned for the greater good, strive for fairness, take responsibility and show respect for each individual and the community. Ethical leaders set high ethical standards and act in accordance with them". They influence the ethical values of the organization or country through their behaviours. Leaders serve as role models for their followers and show them the behavioural boundaries set within a country. They are perceived as honest, trustworthy, courageous and demonstrating integrity. The more the leader "walks the talk", by translating internalized values into action, the higher the level of trust and respect he/she generates from followers.

What all these goes to show is that the very idea of leadership, must necessarily rest on ethics; and when you remove ethics from leadership what we will have is a cartel of individuals who are pursuing their parochial interest at the expense of society (Iroegbu, 2005). Differently put, we cannot divorce politics from ethical considerations. Hence, on a theoretical level, ethical leadership is the fusion of ethical imperatives in the political or managerial leadership of a country or an organization.

\section{National Transformation}

National transformation is a construct of two words national and transformation. National has to do with the central government of a country, shared by the whole people. Transformation means the act of incremental changes. To defend the thesis of change and permanence which was a debate between Heraclitus and Parmenides, Aristotle employs the concept of potency and acts to mediate in the debate. The change we see in a finite being is already in the state of potency which is waiting to be actualized. In other words, change to whatever state is already in the being (metaphysics book II). Precisely, 'transformation' is all about positive change and development within and around a being, in this case, the being of a nation.

National Transformation within the Nigerian context, is the actualization of the ideals and aspirations of Nigerians. Nigeria like any other country in the world needs to experience the dividends of socioeconomic development and modernity. This need should inform all government planning, policy directions, and institutional framing. Nigerians want a thriving economy that creates opportunities for everybody, a just and egalitarian 
society that recognize the self-worth of the people and their resources, a united and strong nation before other nations, a nation of equal opportunities for everyone no matter your ethnicity, religion, gender or political leaning. These aspirations have been expressed in the various National Development Plans, which were conceived, by the various regimes that have ruled Nigeria. It also forms the directive principle of government policies which is enshrined in chapter one of the 1999 Constitution as amended. Therefore, the realizations of these aspirations within the Nigerian context is what can bring national transformation. This entails that our institutions must work, our politics must reflect our national values and our diversities should be our strength, our population should be our asset, not our liability and our people must be at the center of all developmental planning and be made to believe in this dreams. This is where the burden of leadership lays in Nigeria.

Therefore, the linkage between ethical leadership and national transformation finds expression in the vision of a leader who can inspire national consciousness around the aspirations of Nigerians. The leader must be able to carry the burden of leadership, which is service to the people. A leader who can do this must transcend the 'self' and be infused in the spirit of 'greater Nigeria'. A 'greater Nigeria' should be the beacon of our national ideology and the sentiment of our nationalism.

\section{THE PHILOSOPHICAL FOUNDATION OF ETHICAL LEADERSHIP}

Like any other moral concept ethical leadership need to be situated within an ethical theory which will serve as its foundation for evaluation. This is because a moral foundation gives any ethical axiom it fitting, which will make the axiom or idea command moral strength in the process of passing judgments. Moral conducts, behaviour, actions, and inaction are usually evaluated on two extreme moral foundations which are egoism and altruism (Asouzu, 2007:212). Egoism as a moral theory, evaluates actions and inaction, moral conducts and behaviour on the strength of how it promotes the happiness, desires, and interest of the individual or the 'self'. In other words, if an action produces pain, sorrow or hinders a person from pursuing his/her interest that action is adjudged, as been, morally wrong otherwise it is adjudged as being morally right. On the other hand, altruism is a moral theory that evaluates moral conduct, actions, and inaction to how it promotes the wellbeing, happiness, and interest of the other as different from the self. It is an ethical system that abhors all acts of selfishness and self-centeredness. What this entails is that to build a sound foundation for ethical leadership we must seek a mid-ground that can accommodate the imperatives of egoism and altruism comprehensively.

According to Asouzu (2007:212), due to the ambivalence that is inherent in all human existential situations, we are persuaded internally to accept the possibility of morality to be defined within the relative region of the tension between egoism and altruism. This is so because the human person through the instinct of self-preservation sometimes seeks to pursue his/her interest in an egocentric way but at the same time, they are warned to be cautious and considerate to others. Therefore, to curb excessive egocentric morality which can lead to negating the interests of the other, the human person needs to be aware that he is not a being in isolation but a being with others. In pursuing his/her interests, the freedom of the other must be taken into considerations. This is what Asouzu refers to as universal imperative as different from Kant's categorical imperative (duty for the sake of duty). To situates Asouzu's position in the context of our discourse, Wiredu (1992) opines that morality is what promotes human interest within a community of persons and the practical entailment thereof is what he called sympathetic impartiality. This implies that a decision is not moral unless it is characterized by impartiality with 
regards to considering the interests of others, and this consideration must also be characterized by the root of all virtues, sympathy (Molefe, 2016). While the individual is free to pursue his/her individual interest, he/she must do that within the framework of the community which is the harmonization of individual interests to the communal interest. This community-based ethics is what is referred to as Afriethics and it is the foundation of ethical leadership.

Since the whole idea of political leadership is to serve others in a community and not necessarily to serve personal greed, it then implies that political leadership must be based on the promotion of the good of the community. Therefore, to develop a sense of community responsibility is impossible in a society where individualism holds sway. Individualism is normative in an egoistic society, however, its excess can lead to profiteering, prebendalism, and neo-patrimonialism which characterizes the Nigerian political landscape of today. Thus, for ethical leadership to address these challenges it must see the community as supreme which is what African ethics is all about. Since Nigeria is a country in Africa, it follows that its leadership ethos must be community-based which we above briefly highlighted in the previous paragraph. The implication of all these is that leadership is a selfless service that employs the use of power and authority to build a society of peace, order, and wellbeing of the people (Iroegbu, 2005). Therefore the imperatives of ethical leadership ought to be built around values like integrity and honesty, respect and accountability, good stewardship of public resources, accessibility to the public, and open government. We shall discuss these imperatives in the next section.

\section{IMPERATIVES OF ETHICAL LEADERSHIP}

By imperatives we mean those obligations, rules, and constraints which an ethical leader must operate to lead and govern the state or country. Let us briefly explain some of them some the imperatives of ethical Leadership.

\section{Integrity and Honesty}

Integrity is the capacity to act consistently with a moral code that is universally accepted by a people, while honesty, on the other hand, connotes truthfulness and the ability, to tell the truth within a reasonable limit. These two moral imperative work together. A leader who leads with integrity is one who acts within a morally define limit or boundaries and model the same for his followers. He/She knows the rules and has internalized the rule and it reflects in his/her behaviour. Integrity and honesty reflect the leader's willingness to keep to his/her promises. If a leader promises his followers anything, he/she is bound to fulfill it within the limit of reason. While integrity and honesty are trending wording in ethical conversations, they are the essential ingredient that builds trust between the leader and the followers.

Ethical leadership is a leadership philosophy that sees the human person as capable of been incorruptible and transparent, as such, it bears on leadership to exemplify the virtue of integrity and honesty in dealing with followers. The ethical leader must see that he/she keep his promises to the people and be truthful about the state of the country not to manipulate people with propaganda. The leaders that demonstrate integrity are honest with themselves and others, learn from mistakes and are constantly in the process of selfimprovement (Mihelič et al, 2010).

\section{Respect and Accountability}

It takes a leader who respects the people, to be accountable to them. Ethical leadership sees governance or leadership as service to the people and if it is so, it then 
demands that the leader must respect the wishes, aspirations, and expectations of the people. When the leader understands that leadership is something that is given on trust, he/she must necessarily be accountable to the people. This accountability can be financial appropriation, decisions or policies, projects and programmes and dealings with other nations. Ethical leaders must subject all their works to the scrutiny of the people through public opinion and constructive criticism that is geared towards the betterment of the community. Ethical leaders know they are not an island but need the input of the people through their representatives or association to press their positions on any action or inaction of the leaders. This implies that ethical leaders must have the disposition for "consensus conversation" (Wiredu, 1995) and must respect people's opinions, agitations, and fears.

\section{Good Stewardship of Public Resources}

Political leaders by the positions which they occupy are managers and administrators of public resources in achieving the common good. The common good is that good that is defined by the community at any particular point in time. Although, the common good may not be praiseworthy at a time, however, it takes ethical Leadership to consistently interrogates the common good and subject it to critical reflection. Political leaders are the servant of the people elected or appointed to serve the interest of the people. Therefore, the resources which the leader administer are owned by the people and are managing it in trust. He must be a steward of these resources on behalf of the people.

The litmus test for an ethical leader is based on, whether the leader will appropriate public resources for private use. Jesus Christ defines a leader who is a steward of public resources when he opined that "...you know that the men who are considered rulers of the heathen have power over them, and the leaders have complete authority. This, however, is not the way it is among you. If one of you wants to be great, he must be the servant of the rest; and if one of you wants to be first, he must be the slave of all. For even the Son of Man did not come to be served; he came to serve and to give his life to redeem many people" (Mark 11:43-45, Good News Version). What Jesus Christ is trying to establish is that for a leader to be a good steward of public resources he/she must have died to 'self' and its tendencies and be alive to selfless service for the restoration of human dignity and community.

From the above, public resources are not the exclusive right of the leader and his family members but the rights of every person in the community. A good steward is prudent and judicious with his master resources, and in this case, the master is the people. If the leader does not see the resources of the community as the people resources, there is a tendency to steal or misappropriate the same for private or selfish gains. Ethical leaders must necessarily be the steward of public resources.

\section{Accessibility to the Public and Open Government}

Machiavelli (1998) opines that for a leader to rule the state, he must be brutal and kind at the same time but in the case of ruling the State, it better to be brutal or cruel than to be loved. This is because the end justifies the means. This is the attitude that many political leaders are posing to the public, to make their people not to have access to them. This is not so for ethical leaders who are first servants of the people and second stewards of the collective patrimony of the people. Thus, it will be out of place for such kind of leader, to restrain his followers not to have access to him, in order, for them to bear their mind on issues of collective importance. Some people may dismiss this on security 
grounds but we need to know that it is only he that has something to hide that will be shielding himself/herself from people. A leader who is honest in his dealings with the people does not have anything to hide from them.

Also, an open government is one that has a good feedback mechanism and public opinion filter which it uses in engaging the people. An open government is a product of an open society that respects democratic ethos or values, open rationality, and human rights. An open government is an inclusive government that holds the people's needs in high esteem. Corruption thrives in secrecy and it is only an open government, which encourages mass participation that can fight corruption because the people are aware of the essential workings of the government. Since ethical leadership entails that the leader must be the accessibility to the people, it invariably means that the leader must operate an open government that encourages mass participation in decisions and legislation.

\section{ETHICAL LEADERSHIP FOR NATIONAL TRANSFORMATION IN NIGERIA}

In recent times, Nigeria's social, economic and political space has been bastardized with incidents of a widespread corruption scandal, which is perpetuated by some political leaders and their counterparts in the private sector. Today, there is hardly any government agency that is not having one corruption scandal or the other. This sometimes ranges from electoral irregularities, misappropriation of public funds, looting of government treasury, contract inflation and kickback, bribery and forgery, incompetence, mediocrity, and lack of accountability (Ochulor 2011). Nigeria has not had its share of good leadership right from independence to date. More so, all those who have managed and administered the country have not demonstrated the right character that is needed to govern Nigeria. It is on this note that Jegede (2010:145) opines "today, people aspire to positions of leadership without knowing what such offices entail, let alone how they could use such for the benefit of the greatest number of their people". The implication of Jegede's position is that leadership is the mechanism to effect any change in a country and when a nation lacks ethical leaders, development and transformation will keep eluding them. The question is how will ethical leadership engender national transformation in Nigeria?

According to Munroe (2003:66), leadership is about pursuing a higher purpose, inspiring people, empowering people, serving people and being a person of noble aspiration. These ideals are supposed to be embodied in those who are saddled with the responsibility of governance. Leadership failure according to Ochulor (2011:266) is because our leaders lack the intellectual capacity, discipline and political experience which consequently have led to the venality of office. The venality of office is a situation whereby government positions are sold like a commodity. Just as Munroe (2014) stated above, the pursuit of a higher purpose is expressed in the vision of a leader. A leader's vision gives him direction and a sense of purpose in navigating the wheel of the state in a positive outcome. The leader through his team articulates the vision of the state and enshrines it in a concrete plan of development.

This is not the case in Nigeria, rather, what we have in Nigeria is a situation whereby those who come into power are only interested in the pursuit of their parochial interests and those who sponsored them to an office. Therefore, no country will develop in this kind of arrangement. The implication of all these is that due to corrupt leadership in Nigeria, the people are now the victim of mal-administration, poverty, infrastructure decay and moral decadence which have continuously pose as a hybrid monster in our national life. Since corruption and social injustice are now the order of the day, they have consequently led to violent conflicts and agitations for a change of the status quo, which, 
has disadvantaged a lot of Nigerians. Apart from the above, there are other possible causes of violent agitations which have been identified by scholars.

No doubt Nigeria needs a positive change. Therefore, to alleviate or change this situation for the better, we need a new kind of thinking that is ethical and cosmopolitan in nature. This is where ethical leadership is needed to be that beacon for Nigerians to reclaim their country from the hand of few cabals who are in charge of virtually everything and are holding it for themselves and those connected to them. We cannot be transformed as a nation if our leaders and those aspiring for leadership positions are not transformed ethically.

Furthermore, according to section 14 (1) of the 1999 Constitution of the Federal Republic of Nigeria as amended, said "the Federal Republic of Nigeria shall be a State based on the principles of democracy and social justice" and section 17 (1) said "the State social order is founded on ideals of Freedom, Equality, and Justice. Hence, democracy, social justice, freedom, equality, and justice are principles for building a civil society but they must be made to be values in the Nigerian context, which will inform the way we do things in this country. Hence, for these principles to become national values, they must be rooted in the human spirit of the Nigerian people (through spirituality), emotion (through nationalism) and the intellect (through mass education and indoctrination). If these principles which are outlined above are made to become national values, they can be used to build Nigeria; and it is only ethical leaders who hold the sanctity of these values that, can employ them for national transformation. As we seek for the development of the sociopolitico-economic base of the Nigerian society, we need to know that commerce without morality and politics without ethics can be dangerous to civil society. Thus, it takes an ethical leader who has the moral rectitude to inspire change and national transformation for Nigeria. Since such leaders are absent in our political and business space, then corruption, prebendalism, and neo-patrimonialism will be the order of the day. Consequently, the fall out of this state of affairs is that violent conflict and social injustice will hold sway in Nigeria.

\section{CONCLUSION}

The paper examines the conceptual meanings of ethical leadership and national transformation and worked out the moral imperatives of ethical leadership. The paper argues that for ethical leadership in the political space to be relevant to Nigerian national transformation, its philosophical foundations must be based on community-based ethics. This is so because community-based ethics mediate the tensions between egoism and altruism in ethical decision-making. Although 'national transformation' is not the prerogative of political leaders alone, the led also has a role to play. Therefore, when political leaders and followers start acting ethically, Nigeria will indeed experience national transformation. While the problems of social injustice, ethnoreligious agitations, secession movements will be addressed.

\section{REFERENCE}

Achebe C. (1983). The Trouble with Nigeria. Enugu: Fourth Dimension publishing Co. Ltd Aristotle, metaphysics Book II ebook Version

Asouzu I.I (2007). Ibuaru: the heavy burden of philosophy beyond African Philosophy.

Berlin: LIT Verglag Dr W.hopf

Federal republic of Nigeria. 1999 Constitution as amended. Ebook version 
Good News Bible (Today's English Version). St Paul's Publication

Iroegbu P. (2005). Ethics of Leadership. In Iroegbu \& Echekwube (Eds), Kpim of Moral, Ethics - General, Special and Professional. Ibadan: Heinemann Educational Books (Nigeria) PLC

Jegede, S. B. (2012),. 'Poverty, Leadership and the Problem of Africa's Underdevelopment'. In Okeregbe, Jegede and Ogunkoya (Eds), A Study in African Socio-political Philosophy. Akoka: University of Lagos Press

Lee K. Y. (200). From Third World to First World. New York: Harper Collins Publishers Inc.

Machiavelli, N. (1998). The Prince. Oxford: Oxford University Press

Maxwell J. C. (2016). What Successful People Know about Leadership? New York: Hachette Book Group, Inc.

Mihelič K. K., Lipičnik, B \& Tekavčič, M. (2010). Ethical Leadership. International Journal of Management \& Information Systems 14(5) 31-42.

Minkes, A. L., Small, M. W., \& Chatterjee, S. R. (1999). Leadership and business ethics: Does it matter? Implications for management. Journal of Business Ethics, 20(4), $327-$ 335

Moghalu K. (2018). Build, Innovate and Grow - My Vision for our Country. Ibadan: Bookcraft

Molefe M. (2016). African Ethics and Partiality. Phronimon: Unisa Press

Munroe, M. (2014). The Power of Character in Leadership. Nassau: Bahamas Faith Ministries.

Ochulor C. L (2011). Failure of Leadership in Nigeria. American Journal of Social and Management Sciences. 2(3): 265-271

Wikipedia (3rd April, 2019). Lee Kuan Yew. In https://en.wikipedia.org/wiki/lee kuan_yew. Access $4^{\text {th }}$ April 2019, 12:53pm

Wiredu, K (1995). Democracy and Consensus in African Traditional Politics. In Oladipo (Ed), Conceptual Decolonization in African Philosophy. Ibadan: Hope Publications

Wiredu, K. (1992). Moral foundations of an African culture. Person and community: Ghanaian philosophical studies.Washington DC: The Council for Research in Values and Philosophy, pp. 192-206. 